\title{
(1) \\ Acute pancreatitis in diabetics: a two- year retrospective study in a tertiary care hospital in Peshawar, Pakistan
}

\author{
${ }^{1}$ Associate Professor \& \\ Consultant General/Laparoscopic \\ Surgeon, Department of Surgery, \\ Rehman Medical Institute, \\ Peshawar (Pakistan) \\ E-mail: zubair.ahmad.khan71@ \\ gmail.com \\ Cell: +92-333-9129360 \\ ${ }^{2}$ Research Assistant, Rehman \\ Medical College/RMI \\ Hayatabad. Peshawar (Pakistan) \\ E-mail: khalid.saifullah-13@rmi. \\ edu.pk \\ Cell: +92-331-0336215 \\ ${ }^{2}$ Research Assistant, Rehman \\ Medical College/RMI, \\ Hayatabad, Peshawar (Pakistan) \\ E-mail: zunnoora32.marwat@ \\ gmail.com \\ Cell: +92-332-9060576 \\ ${ }^{2}$ Research Assistant, Rehman \\ Medical College/RMI, Hayatabad \\ Peshawar (Pakistan) \\ E-mail: maryam.afridi30@gmail. \\ com \\ Cell: +92-331-9911018 \\ Correspondence: Dr Zubair \\ Ahmad Khan, Department \\ of Surgery, Rehman Medical \\ Institute, Peshawar (Pakistan) \\ E-mail: zubair.ahmad.khan71@ \\ gmail.com \\ Cell: +92-333-9129360
}

\author{
Zubair Ahmad Khan, MBBS, FCPS, FICS ${ }^{1}$, Khalid Saifullah Baig ${ }^{2}$, \\ Zunnoor Ahmad ${ }^{2}$, Maryam Afridi ${ }^{2}$
}

\section{ABSTRACT}

Introduction: Acute pancreatitis (AP) is an acute inflammatory disease of the pancreas. After diagnosis the initial management is preferably done in intensive care unit along with 4-6 hourly insulin sliding scale monitoring for hyperglycemia. Individuals with type II DM are more prone to develop AP. Glycosylated hemoglobin (HbA1c) reflects the blood glucose levels of over past two months and daily glucose levels do not affect its levels in the blood.

Objectives: To find out the frequency of acute pancreatitis in diabetic patients both in type 1 and type 2 .

Study Design: Cross-sectional, comparative study

Methodology: This was a retrospective cross-sectional, comparative study based on 154 patients with acute pancreatitis in our tertiary care hospital over the duration of two years i.e. from January 2016 to December 2017. The data were entered and coded where necessary and statistically analyzed using SPSS version 20. Descriptive analysis was done to summarize data in the form of percentages and numbers for categorical data while continuous variables were shown by using mean and standard deviation.

Results: The mean age was 48.6 year with a standard deviation of 16.9 years, the total cases were 154 for the duration two years from January 2016 to December 2017. Out of 147 patients, 72 (44.4\%) were male and 75 (46.3\%) were female. Only 13 (8.8\%) out of 154 patients were diabetics. Total serum pancreatic lipase and serum pancreatic amylase levels were significantly higher in non-diabetic subjects as compared to diabetics. Also, high serum lipase levels were seen in slightly more females than males.

Conclusion: The results of our study documented that the prevalence of acute pancreatitis is more common in non-diabetics as compared to diabetics, and those who were diabetic were between 41 to 60 years of age. We recommend further studies in this area to reach a general agreement on the prevalence of acute pancreatitis and factors affecting its prevalence as well as on the relation of diabetes and severity of acute pancreatitis.

Key words: Amylase; Biomarkers; Diabetes mellitus; HbA1C; Intensive Care Unit; Lipase; Pancreatitis; Scoring systems

Citation: Khan ZA, Baig KS, Ahmad Z, Afridi M. Acute pancreatitis in diabetics: a twoyear retrospective study in a tertiary care hospital in Peshawar, Pakistan. Anaesthesia, pain \& intensiv care 2019;23(2):211-216

\section{INTRODUCTION}

Acute pancreatitis (AP) is an acute inflammatory disease of the pancreas characterized by a sudden onset of epigastric pain that is typically felt spreading to the back, retching, hiccups, fever, abdominal distention 
and nausea however in severe cases it can lead to necrosis, multiple organ failure and eventual death of the patient. ${ }^{1}$ After diagnosis the initial management is preferably done in intensive care unit for $48-72$ hours which is mainly supportive, 4-6 hourly insulin sliding scale, monitoring for hyperglycemia and upon improvement of scoring system i.e. Ranson's criteria, the patient is shifted to ward. Pancreas normally secretes serum amylase (normal value around 23-85 $\mathrm{U} / \mathrm{L}$ ) and serum lipase (normal value ranges from 0-160 U/L), with serum amylase and lipase levels of more than $200 \mathrm{U} / \mathrm{L}$ pancreatitis is suspected. ${ }^{2}$ Causes of AP include gallstones, high blood fat levels, trauma, alcoholism, viral infections, infections with parasites drugs and autoimmunity. ${ }^{3}$

In the US, AP caused around 275,000 hospitalizations in 2009 (a rise of more than twice since 1988) and is the most common gastrointestinal reason for hospital admissions in the US. ${ }^{4}$ There is a high rate of AP in the fasting population during the Ramadan. ${ }^{5}$ The type 2 diabetic cohort has a 2.83 -fold (95\% CI 2.613.06) greater risk of pancreatitis compared with the nondiabetic cohort. ${ }^{6}$

AP commonly comes with transient hyperglycemia. Studies suggest that individuals with type $2 \mathrm{DM}$ are more prone to develop AP. ${ }^{1}$ Most of the patients of type 2 diabetes are obese which is a risk factor for hypertriglyceridemia and severe hypertriglyceridemia is a risk factor for AP. Obesity is also associated with gallstones which could get impacted in the ampula of Vater and lead to AP. ${ }^{8}$

One of the methods to predict the prognosis of the disease is determined by CT scan (CT severity index). If the scan indicates that the pancreas is only mildly swollen, the prognosis is excellent, If the scan shows large areas of destroyed pancreas, the prognosis is usually poor. ${ }^{9}$ Acute severe pancreatitis is associated with high morbidity and mortality due to complications like obstruction of bile or pancreatic duct, leakage from the pancreatic duct, pseudocysts, with a risk of rupture, hemorrhage, infection, damage to the pancreas, pleural effusion and splenic vein thrombosis. ${ }^{10}$

Recent advances in diagnostic and therapeutic interventions have led to a decrease in mortality from AP, especially in those with severe, often necrotizing pancreatitis. ${ }^{11}$ Deaths in the first two weeks are attributed to a systemic inflammatory response syndrome (SIRS) owing to the release of various cytokines, later complicated by the infection of pancreatic and peripancreatic necrosis and secondary multi-organ failure (MOF). ${ }^{12}$ There are many scoring systems for predicting prognosis of severe AP in Intensive Care Units. These systems also contain glucose values, such as the Ranson scoring system, acute physiology and chronic health evaluation II (APACHE-II) and the Glasgow scoring system. ${ }^{8}$
Glycosylated or glycated hemoglobin referred to as $\mathrm{HbAlc}$, reflects the blood glucose levels of over the previous two months and provides information about the degree of long-term blood glucose control. ${ }^{13} \mathrm{An}$ $\mathrm{HbAlc}$ level of $<42 \mathrm{mmol} / \mathrm{mol}$ or $<6 \%$ is considered normal, $42-47 \mathrm{mmol} / \mathrm{mol}$ or $6.0-6.5 \%$ is considered prediabetic and $48 \mathrm{mmol} / \mathrm{mol}$ and $\geq 6.5 \%$ (cut off for our study) is considered diabetic. An increase in HbAlc levels shows poor diabetic control over long periods of time. ${ }^{14}$ This indicator predicts poorer clinical prognosis in patients with AP..$^{15}$

We conducted this study to find out the frequency of AP in patients known to have diabetes either type 1 or type 2 .

\section{METHODOLOGY}

This was a retrospective cross-sectional comparative study based on 154 patients with AP in our tertiary care hospital at Peshawar (Pakistan) over the duration of two years i.e. from January 2016 to December 2017. All the patients were initially admitted for moderate to severe acute epigastric pain. Further investigations were done at the time of admission to confirm the diagnosis as AP, including serum amylase and serum lipase levels, $x$-ray chest and abdomen, and CT scan abdomen (CT severity index). All the patients were included in the study regardless of their gender or age and all the non-diabetic and prediabetic patients were excluded from the study. Patients with a previous history of diabetes or with $\mathrm{HbAlc} \geq 6.5 \%$ were identified as having AP with diabetes (APD), while patients without a history of diabetes and in whom the $\mathrm{HbAlc}$ was not higher than $6.5 \%$ were considered as AP only and were excluded from the study. The cut off values for both serum amylase and serum lipase to diagnose the case as AP were taken as 160 $\mathrm{U} / \mathrm{L}$. All those having values below $160 \mathrm{U} / \mathrm{L}$ were also excluded from our study.

The data was entered and coded where necessary and statistically analyzed using SPSS version 20. Descriptive analysis was done to summarize data in the form of percentages and numbers for categorical data while continuous variables were shown by using mean and standard deviation.

\section{RESULTS}

The mean age of the patients was $48.6 \pm 16.9 \mathrm{y}$. Total cases studied were 154 reporting during two years from January 2016 to December 2017. Seven patients were excluded sue to one or more reasons. Out of the remaining 147 patients, $72(44.4 \%)$ were male and 75 $(46.3 \%)$ were female.

Patients with a previous history of diabetes or with $\mathrm{HbAlc} \geq 6.5 \%$ were identified as having AP with 
Table 1: Serum amylase levels in diabetic \& non-diabetic patients

\begin{tabular}{|c|c|c|c|c|c|c|c|c|c|c|c|}
\hline \multirow{2}{*}{$\begin{array}{c}\text { Patient } \\
\text { specifications }\end{array}$} & \multirow[b]{2}{*}{$\underset{\text { group (y }}{\text { Age }}$} & \multicolumn{9}{|c|}{ Serum amylase levels (U/L) } & \multirow[b]{2}{*}{ Total } \\
\hline & & $\begin{array}{l}161- \\
460\end{array}$ & $\begin{array}{l}461- \\
760\end{array}$ & $\begin{array}{l}761- \\
1060\end{array}$ & $\begin{array}{l}1061- \\
1360\end{array}$ & $\begin{array}{l}1361- \\
1660\end{array}$ & $\begin{array}{l}1661- \\
1960\end{array}$ & $\begin{array}{l}1961- \\
2260\end{array}$ & $\begin{array}{l}2261- \\
2560\end{array}$ & $\begin{array}{l}2561- \\
2860\end{array}$ & \\
\hline \multirow{2}{*}{ Diabetic } & $41-60$ & 2 & & & 1 & 1 & 3 & & & & 7 \\
\hline & $61-80$ & 1 & & & 0 & 0 & 0 & & & & 1 \\
\hline \multirow{4}{*}{ Non Diabetic } & $0-20$ & 3 & 0 & 1 & 1 & 0 & 1 & 0 & 0 & 1 & 7 \\
\hline & $21-40$ & 11 & 4 & 2 & 1 & 2 & 0 & 1 & 0 & 0 & 21 \\
\hline & $41-60$ & 21 & 7 & 5 & 4 & 1 & 1 & 1 & 0 & 1 & 41 \\
\hline & $61-80$ & 3 & 2 & 3 & 0 & 1 & 1 & 0 & 1 & 0 & 11 \\
\hline \multicolumn{2}{|l|}{ Total } & 42 & 13 & 11 & 7 & 5 & 6 & 2 & 1 & 2 & 89 \\
\hline
\end{tabular}

Table 2: Serum lipase levels in diabetic and non-diabetic patients

\begin{tabular}{|c|c|c|c|c|c|c|c|c|c|c|c|}
\hline \multirow{2}{*}{$\begin{array}{c}\text { Patient } \\
\text { specifications }\end{array}$} & \multirow{2}{*}{$\begin{array}{l}\text { Age } \\
\text { group } \\
\text { (y) }\end{array}$} & \multicolumn{9}{|c|}{ Serum lipase levels (U/L) } & \multirow[b]{2}{*}{ Total } \\
\hline & & $161-460$ & $461-760$ & $\begin{array}{l}761- \\
1060\end{array}$ & $\begin{array}{l}1061- \\
1360\end{array}$ & $\begin{array}{l}1361- \\
1660\end{array}$ & $\begin{array}{l}1661- \\
1960\end{array}$ & $\begin{array}{l}1961- \\
2260\end{array}$ & $\begin{array}{l}2261- \\
2560\end{array}$ & $\begin{array}{l}2561- \\
2860\end{array}$ & \\
\hline Diabetic & $41-60$ & & 1 & 1 & 1 & & & & & & 3 \\
\hline \multirow{5}{*}{ Non Diabetic } & $0-20$ & 0 & 0 & 0 & 1 & 0 & 1 & 1 & 1 & 0 & 4 \\
\hline & $21-40$ & 7 & 2 & 0 & 2 & 0 & 2 & 0 & 1 & 0 & 14 \\
\hline & $41-60$ & 11 & 8 & 5 & 0 & 1 & 0 & 1 & 0 & 1 & 27 \\
\hline & $61-80$ & 8 & 3 & 0 & 0 & 1 & 1 & 0 & 1 & 0 & 14 \\
\hline & $81-100$ & 1 & 0 & 0 & 0 & 0 & 0 & 0 & 0 & 0 & 1 \\
\hline \multicolumn{2}{|l|}{ Total } & 27 & 14 & 6 & 4 & 2 & 4 & 2 & 3 & 1 & 63 \\
\hline
\end{tabular}

Table 3: Gender wise distribution of serum amylase

\begin{tabular}{|c|c|c|c|c|c|c|c|c|c|c|c|}
\hline \multirow{2}{*}{$\begin{array}{c}\text { Patient } \\
\text { specification }\end{array}$} & \multirow[b]{2}{*}{ Gender } & \multicolumn{9}{|c|}{ Serum amylase levels (U/L) } & \multirow[b]{2}{*}{ Tota } \\
\hline & & $\begin{array}{c}160- \\
460\end{array}$ & $\begin{array}{l}461- \\
760\end{array}$ & $\begin{array}{l}761- \\
1060\end{array}$ & $\begin{array}{c}1061- \\
1360\end{array}$ & $\begin{array}{c}1361- \\
1660\end{array}$ & $\begin{array}{c}1661- \\
1960\end{array}$ & $\begin{array}{c}1961- \\
2260\end{array}$ & $\begin{array}{c}2261- \\
2560\end{array}$ & $\begin{array}{c}2561- \\
2860\end{array}$ & \\
\hline \multirow{2}{*}{ Diabetic } & Male & 0 & & & 1 & 0 & 0 & & & & 1 \\
\hline & Female & 3 & & & 0 & 1 & 3 & & & & 7 \\
\hline \multirow{2}{*}{ Non-diabetic } & Male & 20 & 8 & 8 & 2 & 1 & 1 & 1 & 0 & 1 & 42 \\
\hline & Female & 19 & 5 & 3 & 4 & 3 & 2 & 1 & 1 & 1 & 39 \\
\hline \multicolumn{2}{|l|}{ Total } & 42 & 13 & 11 & 7 & 5 & 6 & 2 & 1 & 2 & 89 \\
\hline
\end{tabular}

Table 4: Gender wise distribution of serum lipase

\begin{tabular}{|c|c|c|c|c|c|c|c|c|c|c|c|}
\hline \multirow{2}{*}{$\begin{array}{c}\text { Patient } \\
\text { specs }\end{array}$} & \multirow[b]{2}{*}{ Gender } & \multicolumn{9}{|c|}{ Serum lipase levels (U/L) } & \multirow[b]{2}{*}{ Total } \\
\hline & & $161-460$ & $461-760$ & $\begin{array}{l}761- \\
1060\end{array}$ & $\begin{array}{l}1061- \\
1360\end{array}$ & $\begin{array}{l}1361- \\
1660\end{array}$ & $\begin{array}{l}1661- \\
1960\end{array}$ & $\begin{array}{l}1961- \\
2260\end{array}$ & $\begin{array}{l}2261- \\
2560\end{array}$ & $\begin{array}{l}2561- \\
2860\end{array}$ & \\
\hline Diabetic & Female & & 1 & 1 & 1 & & & & & & 3 \\
\hline Non- & Male & 15 & 5 & 3 & 3 & 1 & 1 & 1 & 2 & 0 & 31 \\
\hline diabetic & Female & 12 & 8 & 2 & 0 & 1 & 3 & 1 & 1 & 1 & 29 \\
\hline Total & & 27 & 14 & 6 & 4 & 2 & 4 & 2 & 3 & 1 & 63 \\
\hline
\end{tabular}


diabetes (APD), while patients without a history of diabetes and in whom the HbAlc was not higher than $6.5 \%$ were considered as AP only. The cut off value for both serum amylase and serum lipase to diagnose the case as AP was taken as $160 \mathrm{U} / \mathrm{L}$. All those having values below $160 \mathrm{U} / \mathrm{L}$ were also excluded from our study.

The most common age group of patients was 41-60 $y$, with overall male preponderance. The highest detected range of serum amylase (2560-2860 U/L) was found in just two patients, one diabetic and one non diabetic. Majority of the patients was having serum amylase levels in the range of 160-460 U/L i.e. 42 patients. The most common presenting values of serum lipase were in the range of 161-460 U/L i.e. 27 patients. The highest range of serum lipase (25612860) had only one patient. Most common age group with raised serum Lipase levels was between 41-60 years of age, 30 in total with 27 non diabetic and 3 diabetic patients.

Serum total amylase levels in diabetics and nondiabetics of various age groups are shown in Table 1. Normal serum amylase levels range from 23-85 U/L while in some labs range goes up to $140 \mathrm{U} / \mathrm{L}$. Table 1 shows all the subjects having higher serum amylase levels than normal. A total number of subjects which was recorded to be 7 in $0-20$ age group with diabetes were equal to the number of subjects of the same age group without diabetes having high serum amylase than normal. Also, there was no significant difference between the number of subjects which was recorded to be 21 in 21-40 age group, diabetic and non-diabetic, having high serum amylase levels.

In 41-60 age group of diabetics the serum amylase levels were recorded to be high in 7 subjects, comparatively, the 41-60 age group of nondiabetics had significantly more subjects i.e. 41 having high serum amylase levels. There was a significant difference in the total number of subjects in 61-80 age group having diabetes and those not having it with high serum amylase levels. Only 1 diabetic subject was recorded to have high serum amylase in 61-80 age group. While 11 non-diabetic subjects are recorded to have high serum amylase levels. Thus, in nondiabetic subjects with the increase in age there is a significant increase in the number of subjects having high serum amylase levels but after the age of 60 , there is a significant decrease in the subjects.

Serum total lipase levels in diabetics and nondiabetics of various age groups are shown in Table 2. Normal serum lipase levels range from 0-160 U/L. Total of 63 subjects of different age groups with high serum lipase levels were divided into diabetics and non-diabetics (Table 2). Thus, according to this table, the results reveal that significantly high number of subjects are non-diabetic having high serum lipase levels. Also, the number of subjects with high serum amylase levels increase from 0-20 to 41-60 age groups. From $61-80$ age group onwards the number of subjects decreased.

Total serum amylase levels were computed separately for men and women, and are shown in Table 3. There were a total of 89 subjects, in which, 43(48.3\%) were males and $46(51.6 \%)$ were females. Both the genders were divided into diabetics and non-diabetics. In a total of 8 diabetic subjects, $1(12.5 \%)$ male and $7(87.5 \%)$ females had high serum amylase levels. While in a total of 81 nondiabetic subjects, $42(51.8 \%)$ males and 39(48.1\%) females had high serum amylase levels. Total amylase levels were significantly higher in non-diabetic subjects as compared to diabetics. Also, high serum amylase levels were seen in more females than males.

Serum total lipase levels were separately computed for males and females, and are shown in Table 4. There were a total of 63 subjects, in which, 31 were males and 32 were females. Both the genders were divided into diabetics and non-diabetics. In a total of 3 diabetic subjects, there were no males and all the 3 subjects were females having high serum lipase levels. While in a total of 60 non-diabetic subjects, 31 males and 29 females had high serum lipase levels. Total serum lipase levels were significantly higher in non-diabetic subjects as compared to diabetics. Also, high serum lipase levels were seen in slightly more females than males.

\section{DISCUSSION}

The most susceptible mean age found in our study was $48.6 \pm 16.9 \mathrm{y}$, while that in another study ${ }^{16}$ done by a Pakistani researcher Saaiq was $44 \pm 17$ y. In another study ${ }^{17}$ done in a tertiary hospital in Jamaica, the mean age was $45.68 \pm 19.64$ y. Our study found that AP is slightly more common in females than in males i.e. $51 \%$ in female and $49 \%$ in males. Another study showed that there were 58\% males and $42 \%$ females which were almost similar results. ${ }^{18}$ The most common range of serum amylase found in our study was $160-460 \mathrm{mg} / \mathrm{dl}$, whereas some other researchers ${ }^{19}$ found the levels to be $>300 \mathrm{mg} / \mathrm{dl}$. Only $2 \%$ of patients had serum amylase levels more than $2200 \mathrm{mg} / \mathrm{dl}$. A research group found the serum lipase levels to be $>570 \mathrm{mg} / \mathrm{dl},{ }^{19}$ but our study found that the most common range found in AP was 161-460 $\mathrm{mg} / \mathrm{dl}$ followed by $461-760 \mathrm{mg} / \mathrm{dl}$. We found that the prevalence of diabetics diagnosed with AP was $8 \%$ which is in accordance with $12.8 \%$ in a study done by Saaiq. ${ }^{16}$ The age groups from $0-40$ years had no diabetic patients in them, between 41-60 years of age most of the diabetics were found i.e. $69.23 \%$. Other researchers found the prevalence of $47.1 \%$ in the age group of $45-64 .^{20}$ Another study done by Urushihara $\mathrm{H}$ and co-workers used a Japanese hospital database 
where the age group 60-79 y had a prevalence of $55.8 \%{ }^{21}$ Most of the diabetic patients with AP were females i.e. $84.61 \%$ which is in contrast with the $26 \%$ prevalence in females done in a study ${ }^{1}$ by Kikuta $\mathrm{K}$ and co-workers.

\section{CONCLUSION}

Our study showed that serum pancreatic lipase is a more accurate biomarker than serum pancreatic amylase in our setting, with almost negligible male to female preponderance. It was also documented that the prevalence of acute pancreatitis is more common in non-diabetics as compared to diabetics.

The most common age group for developing acute pancreatitis in diabetics is $41-60$ according to our study. We recommend further studies in this region to reach a general agreement on the frequency of acute pancreatitis and factors affecting it, as well as on the relationship of diabetes and severity of acute pancreatitis.

Conflict of interest: Nil

Authors' contribution:

ZAK; Data Collection, Concept, Data Analysis and Overall Supervision

KSB; Data Interpretation and Manuscript Writing

ZA; Literature Review

MA; Data Tabulation 


\section{REFERENCES}

1. Kikuta K, Masamune A, Shimosegawa T. Impaired glucose tolerance in acute pancreatitis. World J Gastroenterol. 2015;21(24):7367-74. [PubMed] DOl: 10.3748/wjg.v21. i24.7367

2. Quinlan JD. Acute pancreatitis. Am Fam Physician. 2014;90(9):632-9. [Free full text]

3. Cappell MS. Acute pancreatitis: etiology, clinical presentation, diagnosis, and therapy. Med Clin North Am. 2008;92(4):889-923. [PubMed] DOI: 10.1016/j.mcna.2008.04.013

4. Yadav D, Lowenfels AB. The epidemiology of pancreatitis and pancreatic cancer. Gastroenterology. 2013;144(6):1252-61. [PubMed] DOl: 10.1053/j.gastro.2013.01.068

5. Herman RZ, Shiber $S$, Dresher $M$, Agabaria A, Bleetman T, Drozdinsky G. High prevalence of acute pancreatitis during the ramadan fast. Prehospital Disaster Med. 2017;32(S1):S62-S62. DOI: 10.1017/S1049023X17001686

6. Noel RA, Braun DK, Patterson RE, Bloomgren GL. Increased risk of acute pancreatitis and biliary disease observed in patients with type 2 diabetes: A retrospective cohort study. Diabetes Care. 2009;32(5):834-8. [PubMed] DOI: 10.2337/dc08-1755

7. Berglund L, Brunzell JD, Goldberg AC, Goldberg IJ, Sacks F, Murad $\mathrm{MH}$, et al. Evaluation and treatment of hypertriglyceridemia: an endocrine society clinical practice guideline. J Clin Endocrinol Metab. 2012;97(9):2969-89. [PubMed] DOl: 10.1210/jc.2011-3213

8. Malik AM. Acute pancreatitis. A more common and severe complication of gallstones in males. Int $\mathrm{J}$ Health Sci (Qassim). 2015;9(2):141-5. [PubMed]

9. Alhajeri A, Erwin S. Acute pancreatitis: value and impact of CT severity index. Abdom Imaging 2008;33(1):18-20. [PubMed] DOI: 10.1007/s00261-0079315-0

10. Zerem E. Treatment of severe acute pancreatitis and its complications. World J Gastroenterol. 2014;20(38):13879-92. [PubMed] DOl: 10.3748/wjg.v20.i38.13879

11. Janisch NH, Gardner TB. Advances in management of acute pancreatitis. Gastroenterol Clin North Am. 2015;45(1):1-8. [PubMed] DOI: 10.1016/j.gtc.2015.10.004

12. Carnovale A, Rabitti PG, Manes G, Esposito P, Pacelli L, Uomo G. Mortality in acute pancreatitis: is it an early or a late event? JOP. 2005 Sep 10;6(5):438-44. [PubMed]

13. Sherwani SI, Khan HA, Ekhzaimy $A$, Masood A, Sakharkar MK. Significance of $\mathrm{HbA1C}$ Test in Diagnosis and Prognosis of Diabetic Patients. Biomarker Insights. 2016;11:95-104. [PubMed] D0I: 10.4137/BMI.S38440

14. Florkowski C. HbA1c as a diagnostic test for diabetes mellitus - reviewing the evidence. Clin Biochem Rev. 2013;34(2):75-83. [PubMed]

15. Zhao X, Mei HC, Chen L, Jiang L, He $M$, Chen J, et al. An increased level of haemoglobin A1C predicts a poorer clinical outcome in patients with acute pancreatitis. Clin Endocrinol. 2012;77(2):241-5. [PubMed] DOI: 10.1111/j.1365-2265.2011.04252.x
16. Siddiqui ZR, Inam A, Saaiq M, Nud D, Zaheer M, Jamal S, et al. Presentation and outcome of acute pancreatitis at pakistan institute of medical sciences, Islamabad.

17. Reid GP, Williams EW, Francis DK, Lee MG. Acute pancreatitis: A 7 year retrospective cohort study of the epidemiology, aetiology and outcome from a tertiary hospital in Jamaica. Ann Med Surg (Lond). 2017;20:1038. [PubMed] DOI: 10.1016/j. amsu.2017.07.014

18. Vidarsdottir $\mathrm{H}$, Möller PH, Vidarsdottir $H$, Thorarinsdottir $H$, Björnsson ES. Acute pancreatitis: a prospective study on incidence, etiology, and outcome. Eur J Gastroenterolo Hepatol. 2013;25(9):1068-75. [PubMed] DOl: 10.1097/MEG.0b013e3283640fc8

19. Smith RC, Southwell-Keely J, Chesher D. Should Serum pancreatic lipase replace serum amylase as a biomarker of acute pancreatitis? ANZ J Surg. 2005;75(6):399-404. [PubMed] DOI: 10.1111/j.1445-2197.2005.03391.x

20. Alva ML, Hoerger TJ, Zhang P, Gregg EW. Identifying risk for type 2 diabetes in different age cohorts: does one size fit all? BMJ Open Diabetes Res Care. 2017;5(1) :e000447. [PubMed] DOl: 10.1136/bmjdrc-2017-000447

21. Urushihara $H$, Taketsuna M, Liu $Y$, Oda E, Nakamura M, Nishiuma S, et al. Increased risk of acute pancreatitis in patients with type 2 diabetes: an observational study using a japanese hospital database. PLOS ONE. 2012;7(12):e53224. [PubMed] DOI: 10.1371/journal.pone.0053224 